\title{
Educação Indígena: escolarização e políticas voltadas à área de educação especial
}

\author{
Students with disabilities and/or special needs at school: \\ politics and applied laws
}

\section{Educación Indigena: escolarización y politicas orientadas a la area de educación}

\author{
Jucélia Linhares Granemann de Medeiros ${ }^{1}$ \\ ORCID: https://orcid.org/0000-0002-3470-8723 \\ Sonia Grubits ${ }^{2}$ \\ ORCID: https://orcid.org/0000-0002-3470-8723
}

Resumo: $\mathrm{Na}$ atualidade muito se discute sobre os direitos conquistados pelas pessoas, cujas características físicas, psicológicas, educacionais e/ou sociais diferem significativamente dos padrões de normalidade ditados pela sociedade. A oportunidade de estar com os demais, compartilhando de espaços e interações, é algo defendido em todas as esferas, sejam elas públicas ou privadas. Tratase, em geral, de um novo paradigma que vem despontando, que prima pelo tratamento igualitário e respeitoso a todos os indivíduos, independentemente de qualquer norma, idade, etnia, escolaridade ou outra condição. Nessa perspectiva, o processo de inclusão de alunos indígenas com deficiências na escola é desses exemplos, representando uma nova proposta que gradativamente vem transformando todo o cenário nacional, incentivando novos estudos e debates, com vistas à implementação de políticas e ações que deem suporte ao oferecimento de um ensino de qualidade, aberto, plural, especializado na diversidade de educandos, oriundos de qualquer segmento da sociedade. Nesse sentido, este artigo visa a mapear tal quadro, estimulando a luta pela implantação de atendimentos e serviços especializados na área de educação especial a essa clientela.

Palavras-chave: Educação especial. Educação indígena. Escola. Políticas públicas.

Abstract: Nowadays a lot is said or discussed about possibilities and the right of children's and teenagers with disabilities and/or special needs scholarship at schools. This way, it is observed different politics and oficial documents coming from Municipal, State and Federal instance, that reinforce the importance to fullfil - in an effective way - the proposal of adding this clientele at scholarship. At this organization, not one disabled or in special educative need student is enrolled at children's education, elementary school, high school or college education may maintain part of this proposition. On it, any student regardless kind and difficulty or defiency level (since it may has the requirements to be included at school) must be worked with fellow students. At this proposal, school has the comitment of planning and redesigning activities, resources, relationships and evaluated

\footnotetext{
1 Doutora em Educação pela Universidade Federal de Mato Grosso do Sul. Pós-Doutora em Educação pela Universidade Federal do Espirito Santo. Docente da Universidade Federal de Mato Grosso do Sul, Campus de Três Lagoas (UFMS/TL). E-mail: juclia313@yahoo.com.br

${ }^{2}$ Possui graduação em Psicologia pela Pontifícia Universidade Católica do Rio de Janeiro, graduação em Jornalismo pela Universidade Federal do Rio de Janeiro, mestrado em Psicologia (Psicologia Social) pela Pontifícia Universidade Católica de São Paulo (1992) e doutorado pela Universidade Estadual de Campinas (1996). Doutorado com status de pós-doutorado por Paris 8 Sorbonne, Paris, França. Pós-doutorado em Saúde Mental no Trabalho pela UNICAMP. Docente do Programa de Pós-graduação Universidade Católica Dom Bosco- Psicologia. E-mail: sgrubits@gmail.com
} 
Educação Indígena: escolarização e políticas...

ways, covering a diversity of situations and/or pictures. Between the politcs that support the most and defend this right, it is the Federal Constitution of 1988, the Statute of the Child and the Adolescent, law No 8.069, of 13th of July of 1990, Law of directive and Bases of National Education, law No 9.394, of 20th of december of 1996, among others resolutions, statements and proposal made by the Ministry of Education, at this leased.At this process, it is parallely seemed the existence of educational support services specialized at different knoledge/development areas. The educational attendance at hospital enviroment; service this nowadays directed by the especial education is an example at those attendances. In general, it is known that its functional is to guarantee its continuaty at schorlarship process of hospitalized and/or in health treatment students. it is also held by national and international documents and guideline, allowing teacher's hiring and building a pedagogic work, making - as a whole - academic and general development of the student.

Key words: Attendance. Politics. Especialized service. Disabilities. Special educational needs.

Resumen: En la actualidad mucho se discute sobre los derechos conquistados por las personas cuyas características físicas, psicológicas, educacionales yo sociales difieren significativamente de los padrones de normalidad dictados por la sociedad. La oportunidad de estar con los demás, compartillando de espacios y interacciones, es algo defendido en todas las esferas, Sean ellas públicas o privadas. Se trata, en general de un nuevo paradigma que viene despuntando, que prima por el tratamiento igualitario y respetuoso a todos los individuos, independientemente de cualquier norma, edad, etnia, escolaridad o otra condición. En esta perspectiva, el proceso de inclusión de alumnos indígenas con deficiencia en la escuela es uno de los ejemplos, representando una nueva propuesta que gravativamente viene transformando todo el escenario nacional, incentivando nuevos estudios y debates, con vistas a la implementación de políticas y acciones que den soporte al ofrecimiento de una enseñanza de calidad, abierto, plural, especializado en la diversidad de educandos oriundos de cualquier segmento de la sociedad. En ese sentido, este articulo visa a mapear tal cuadro, estimulando la lucha por la implantación de atendimientos y servicios especializados en la área de educación especial para ese tipo de clientes.

Palabras clave: Educación especial. Educación indígena. Escuela. Políticas públicas.

\section{APRESENTAÇÃO}

Atualmente, as políticas públicas vêm buscando nortear a interface da educação especial com a educação escolar indígena, porém alguns estudos vêm demonstrando diversas dificuldades e lacunas. De modo geral, esse tema que vem sendo bastante debatido em diversas instâncias nos últimos anos, sendo inclusive contemplado na Constituição Federal de 1988 (CF/1988), a qual assegura o direito a educação a todas as crianças e os jovens independentes de sua classe social, raça, etnia e cor, garantindo-Ihes uma educação diferenciada, sendo utilizadas suas línguas maternas no contexto de suas escolas (BRASIL, 1999, art. 210).

Nessa perspectiva, para Cohn (2005), foi a partir da promulgação da $\mathrm{CF} / 1988$, que a população indígena, efetivamente, passou a ter direito à educação escolar, enquanto ao Estado coube o seu provimento, respeitando sua cultura, sua língua e seus processos próprios de ensino e aprendizado de cada comunidade. Nesse sentido, verifica-se que a educação escolar indígena, almejada por diferentes 
comunidades, foi assegurada constitucionalmente, vindo a apontar um novo modelo de educação escolar, marcada pelo direito à diferença.

Nesse patamar, Meliá (1999) refere que esse processo deve permitir aos povos indígenas continuar sendo eles mesmos, mantendo a transmissão de suas culturas por várias gerações. Desse modo, há necessidade de essa educação ser gerenciada pelas comunidades e ministrada por professores indígenas, pois são eles não somente meros transmissores de conteúdo, mas, sim, transmissores de suas culturas e línguas.

Conforme Grubits e Sordi (2017), a Declaração da Organização das Nações Unidas (ONU), em 2007, sobre os Direitos dos Povos Indígenas: reconheceu as injustiças passadas cometidas contra os povos indígenas e que afetam suas vidas e bem-estar no presente (portanto constitui importante elemento para a conscientização dessa opressão histórica contra esses povos); afirma que eles, além de estarem aqui presentes também querem preservar suas culturas e tradições (rompendo com a mentalidade assimilacionista e com o estereótipo e preconceito contra a identidade e cultura indígena). Afirma também que os povos indígenas são seres humanos e têm direitos iguais (eles são protegidos pelos demais instrumentos internacionais de direitos humanos), que têm o direito de existir e de continuar a tomar suas próprias decisões sobre como querem viver e se desenvolver, não estabelece direitos, mas apenas reconhece e afirma os direitos inerentes dos povos indígenas. Reconhece que eles têm direitos como comunidades, nações ou povos, faz menção a direitos coletivos dos povos indígenas ademais dos direitos individuais; Chama os Estados a tomarem medidas para ajudar e garantir que esses povos sejam verdadeiramente livres, detendo livre determinação, para reparar os erros e injustiças do passado cometidas contra eles, e - quando necessário e desejado por eles - para que o Estado não se envolva nas decisões dos povos indígenas em assuntos que lhes dizem respeito.

Nessa direção, o Relatório das Nações Unidas para a Infância, Garantindo os Direitos de Crianças Indígenas, acrescenta que os povos indígenas 3 "são grupos

\footnotetext{
${ }^{3}$ Segundo o Censo Demográfico, realizado pelo IBGE (2010) "[...] os povos indígenas em geral, compõem $0,47 \%$ da população brasileira, isto é, eles são 817.963 habitantes pertencentes a 305 etnias e falantes de 274 línguas; 502.783 deles vivem na zona rural e 315.180 , em zonas urbanas. Tratando-se das deficiências por eles apresentadas e/ou adquiridas pouco se fala ou se discute. $O$ censo estatístico, realizado pelo IBGE, em 2005, observou que existem índios em todas as regiões do Brasil, e entre as 734 mil pessoas que se autodeclararam indígenas, "125.225 pessoas destacaram apresentar algum tipo de deficiência, o equivalente a 17,1\% dessa população" (IBGE, 2006). A situação
} 
Educação Indígena: escolarização e políticas...

marginalizados e discriminados, sofrem com altas taxas de mortalidade infantil, ausência de cuidados médicos, pouca oferta de escolas, sendo o seu ensino de uma precária qualidade" (UNICEF, 2004). Nessas circunstâncias, ressalta-se paralelamente que esse quadro se agrava mais ainda quando esses educandos apresentam algum tipo de deficiência, seja ela sensorial (surdez, cegueira), física ou intelectual, ocorridas por falta de prevenção ou cuidados peri, pré ou pós-natal, por condições socioeconômicas desfavoráveis, fatores orgânicos, hereditários ou genéticos, ou ainda adquiridas, muitas vezes por acidentes onde não foram levados em consideração os riscos físicos e ambientais.

O referido documento aponta, também, que os indígenas são vistos pela sociedade dominante como figuras estranhas, indefesas, incapazes de comunicar e de ser autônomos. Nesse sentido, visões estereotipadas são generalizadas pela população principalmente quando o assunto causa grande impacto, como é caso do infanticídio praticado por algumas etnias, com crianças que nascem deficientes e que tem sido denunciado pela mídia impressa e eletrônica. Tais informações povoam o imaginário de grande parte da população, que acredita que todas as etnias indígenas são iguais e sacrificam as crianças que nascem com alguma deficiência, pois a maioria da população, inclusive muita dos responsáveis pela educação, desconhece as diferentes maneiras de pensar de viver e organizar - se social, econômica e politicamente.

Quanto à questão das deficiências, destaca-se, ainda, que as populações indígenas encontram-se em situação de fragilidade social e a falta de diagnóstico quanto ao número e a situação em que se encontram os indígenas com deficiências inviabiliza toda e qualquer atuação no que se refere ao atendimento educacional terapêutico, psicológico dessas pessoas que compõem essa população, que há séculos sofrem exclusão econômica e social, marginalização política, abuso e exploração comercial,

Nessa problemática, Sá (2011) cita que, na população indígena Guarani e Kaiowá da região sul de Mato Grosso do Sul, se constataram crianças e jovens com esse tipo de deficiência e que não tinham diagnóstico e não tiveram oportunidade de passar por exames oftalmológicos para tratamento e prevenção da deficiência visual 
e dos problemas oculares, evidenciando a ausência de políticas públicas de atenção à saúde.

Paralelamente, sabe-se que há pessoas com deficiência que vivem no campo e há alunos com deficiência que vivem no campo e estão matriculados em escolas das áreas rural ou urbana, crianças e jovens com deficiência que vivem em terras indígenas, comunidades remanescentes de quilombos, assentamentos, comunidades ribeirinhas e demais áreas rurais em nosso país (IBGE,2010) BRASIL, 2012a). Quanto a essa clientela, pouco se fala e/ou se discute. Recentemente, a legislação tem considerado que as ações na área da educação especial devem considerar as áreas rurais, bem como a educação do campo, de indígenas ${ }^{4}$ e quilombolas, e garantir a interface com a educação especial. A Resolução $n^{0}$ 2/2008 (BRASIL, 2008a), específica da educação do campo, afirma que: "§5 - Os sistemas de ensino adotarão providências para que as crianças e os jovens com deficiências, objeto da modalidade de educação especial, residentes no campo, também tenham acesso à Educação Básica, preferentemente em escolas comuns da rede de ensino regular".

Ao se verificar o processo de inclusão desses alunados na escola, observa-se que, embora tracem-se inúmeras propostas e alternativas de trabalho, destinadas a incluí-los no ambiente escolar, ainda existem inúmeras barreiras a serem transpostas. Para melhor entender esse movimento, faz-se também, necessário compreender a trajetória dessa educação, na qual podem-se observar momentos distintos na história da educação no Brasil.

Primeiramente, Viveiros de Castro (2002), ao contextualizar esse processo, cita a implantação de um modelo de educação escolar coordenado por ordens religiosas, em especial, a Companhia de Jesus, cujo objetivo voltava-se para a estruturação de uma modalidade de escola que teve por alvo principal o "curumim" e

\footnotetext{
${ }^{4} \mathrm{~A}$ atual Constituição, promulgada em 1988, dedicou aos índios um capítulo específico, com direitos e garantias fundamentais e assim refere-se, no capítulo VII - dos índios no artigo 231 "São reconhecidos aos índios sua organização social, costumes tradições, e os direitos originários sobre as terras que tradicionalmente ocupam, cabendo à União demarcá-las, proteger e respeitar todos os seus bens" (BRASIL, 1999). Todas as constituições republicanas brasileiras (exceto a de 1891) reconheceram, aos povos indígenas, direitos sobre os territórios por eles habitados, embora sempre guiadas pelo pressuposto de que esses povos estavam fadados à perda de sua identidade mediante uma gradual absorção pela sociedade dos "brancos". Entretanto, a Constituição de 1988 vai mais longe no tocante aos direitos indígenas, reconhecendo a organização social, costumes, línguas, crenças e tradições desses povos, além dos "direitos originários sobre as terras que ocupam, competindo, à União, demarcá-las, proteger e respeitar todos os seus bens" (BRASIL, 1999, grifo nosso). É responsabilidade da União, por intermédio da Fundação Nacional do Indio (FUNAI), assegurar, aos povos indígenas, o exercício desses direitos.
} 
Educação Indígena: escolarização e políticas...

que foi desenvolvida desde o século XVI, como mostram documentos da época, principalmente as cartas de padres que atuaram no período colonial e relatam seus esforços para cristianizar, civilizar e europeizar os povos autóctones, considerados por eles sem fé, sem rei e sem lei.

Seguidamente, segundo o autor, foi instituído o "plano civilizador", este diretamente relacionado aos indígenas, explicitado por Nóbrega em 1558. Ele visava a "defender-Ihe comer carne humana e guerrear sem licença do governador"; "fazerIhes ter uma só mulher"; "vestirem-se"; "tirar-Ihes os feiticeiros"; "fazê-los viver quietos sem se mudar para outra parte, tendo terras repartidas que lhes bastem". Com pequenas diferenças nos distintos tempos e espaços do Brasil colônia, esses princípios se mantiveram nos séculos de colonização, reforçados pela atuação de outras ordens religiosas, como os beneditinos, franciscanos, carmelitas, lassalistas e salesianos, e retomados pelo Estado brasileiro no início do século $\mathrm{XX}$, quando se configura um segundo momento da educação escolar indígena. A partir da criação do Serviço de Proteção ao Índio e Localização dos Trabalhadores Nacionais (SPILTN), em 1910, foram colocados sob a tutela do Estado, que desde o advento da República passou a atuar de forma mais incisiva para territorializar, civilizar e integrar os povos indígenas na chamada sociedade nacional. Em cada "reserva" indígena, um posto do Serviço de Proteção ao Índio (SPI), e, em cada posto, uma escola, cujo teor de atuação foi assim destacado por Souza Lima (1995).

Conforme Souza Lima (1995), nesse momento, trabalhavam-se noções elementares da Língua Portuguesa (leitura e escrita) e estímulo ao abandono das línguas nativas, além de se introduzir uma série de pequenas alterações no cotidiano do povo indígena, a partir de formas de socialização características de sociedades que têm na escola seu principal veículo de reprodução cultural. O modelo de governo idealizado, e que foi em certos casos implementado, procurava atingir a totalidade das atividades nativas, inserindo-se em tempos e espaços diferenciados dos ciclos, ritmos e limites da vida indígena. Desde as primeiras décadas do século XX, escolas técnicas atuaram na direção de formar mão de obra, dentro dos objetivos posto pelo SPILTN, compondo o cenário da educação escolar indígena daquele período e impondo um modelo integrador que apontava para a extinção dos povos originários. Mesmo com a presença do Estado, que se pretendia laico, muitas ordens religiosas se mantiveram atuando entre os povos indígenas no século XX, algumas de comum acordo, até mesmo selando convênios com o 
governo republicano, por meio do SPI e mais tarde da Fundação Nacional do Índio (FUNAI), possibilitando assim a continuidade da presença religiosa na educação escolar dos povos indígenas, embora com outros parâmetros de atuação.

Nessa trajetória ainda, o autor relembra que, em 1967, foi substituído o SPI e criada a FUNAI. Pequenas mudanças ocorreram nas práticas escolares. Uma delas referiu-se à atuação do Summer Institute of Linguistics (SIL). Esse instituto, com base em convênio firmado com o Estado brasileiro, levou para as áreas indígenas linguistas de outras nacionalidades, muitos deles ligados a missões religiosas, os quais passaram a atuar no sentido de criar a escrita da língua de diversos povos. A escola nas aldeias passou a ser direcionada por uma lei do Ministério do Interior (Lei no $6.001,1973$, arts. 49-50) $)^{5}$, que indica o uso da língua de cada grupo, concomitante ao português, nos processos de alfabetização. A referida lei prescreve que "a educação do índio será orientada para a integração na comunhão nacional mediante processo de gradativa compreensão dos problemas gerais e valores da sociedade nacional, bem como do aproveitamento de suas aptidões individuais".

Dessa forma, para se implementar o ensino das línguas nativas nas escolas indígenas criou-se o cargo de monitor bilíngue, em geral um jovem da aldeia que recebia formação para desempenhar o papel de tradutor entre os alunos monolíngues e o professor não indígena, o qual ensinava o português e as demais

\footnotetext{
${ }^{5}$ No Brasil, a Lei no 6.001, de 19 de dezembro de 1973, dispõe sobre o Estatuto do Índio tendo princípios e definições que indicam questões referentes à cultura, às relações com a sociedade brasileira de um modo geral. No título I, art. 1ํㅡ, o propósito é de preservar a cultura indígena e integrá-los, progressiva e harmoniosamente, à sociedade nacional. Entendemos que a proposta, ao mesmo tempo em que pontua a preservação da cultura, propõe uma integração progressiva e harmoniosa à sociedade não índia e finalmente estende a proteção das leis que se aplicam aos brasileiros às comunidades indígenas. No art. $2^{\circ}$ determina que "Cumpre à União, aos Estados e aos Municípios, bem como aos órgãos das respectivas administrações indiretas, nos limites de sua competência, a proteção das comunidades indígenas e a preservação dos seus direitos".Assim, estender aos índios os benefícios da legislação comum, sempre que possível a sua aplicação; determina a prestação de assistência aos índios e às comunidades indígenas ainda não integrados à sociedade nacional; propõe proporcionar aos índios meios para o seu desenvolvimento, as peculiaridades inerentes à sua condição; assegura aos índios a possibilidade de livre escolha dos seus meios de vida e subsistência; garante aos índios a permanência voluntária no seu habitat, proporcionando-Ihes ali recursos para seu desenvolvimento e progresso; determina respeito no processo de integração do índio à sociedade nacional, a coesão das comunidades indígenas, os seus valores culturais, tradições, usos e costumes; propõe também a execução, sempre que possível mediante a colaboração dos índios, dos programas e projetos tendentes a beneficiar as comunidades indígenas, assim como a utilização da cooperação, do espírito de iniciativa e das qualidades pessoais do índio, tendo em vista a melhoria de suas condições de vida e a sua integração no processo de desenvolvimento; finalmente, garante aos índios e comunidades indígenas, nos termos da Constituição, a posse permanente das terras que habitam, reconhecendoIhes o direito ao usufruto exclusivo das riquezas naturais e de todas as utilidades naquelas terras existentes; garante aos índios o pleno exercício dos direitos civis e políticos que em face da legislação lhes couberem. (GRUBIT; SORDI, 2017).
} 
Educação Indígena: escolarização e políticas...

matérias escolares, todas proferidas na língua nacional. Em geral, a escrita da língua indígena, ensinada no primeiro ano escolar, servia de passagem para o aprendizado do português e para a introdução, entre os indígenas, de conhecimentos e visões de mundo da sociedade nacional.

Nessa nova organização, Souza Lima (1995) explica que o cargo de professor indígena, entre outras conquistas, foi decorrente de um processo de luta que reivindicava o protagonismo indígena na elaboração e execução de políticas públicas, entre elas a educação escolar. Iniciava-se na década de 1970 um movimento incisivo de organização dos povos originários que, com o apoio de setores da Igreja, da universidade e de organizações não governamentais (ONGs), e em consonância com os movimentos indígenas internacionais, explicita suas reivindicações pelo direito à diferença, à terra, à saúde e à educação diferenciada.

Nesse cenário foi, segundo Brasil (1998), a partir da atuação indígena no processo constituinte da década de 1980, que a Constituição Federal em 1988 assegurou direitos importantes as suas sociedades, entre eles o direito à escola diferenciada. A Carta Magna (BRASIL, 1999) reconheceu aos índios, no art. 231, "sua organização social, costumes, línguas, crenças e tradições", e no art. $210, \S 2^{\circ}$, "a utilização de suas línguas maternas e processos próprios de aprendizagem", ou seja, garantiu-lhes um ensino no idioma próprio, com processos pedagógicos que possibilitem aprender de acordo com sua cultura. As escolas indígenas que até então estavam vinculadas à FUNAI e, portanto, ao Ministério do Interior, em 1991 passam para o Ministério da Educação. A partir daí desencadeia-se um movimento forte de afirmação da educação escolar indígena, por meio de leis, de criação de setores específicos para a gestão dessa modalidade de escola e do envolvimento de lideranças e professores indígenas na condução desse processo.

Já por intermédio da Lei de Diretrizes e Bases da Educação Nacional (LDB) (Lei no 9.394/1996), reafirmaram-se algumas questões pontuadas na Constituição Federal, estabelecendo, também, uma "educação escolar bilíngue e intercultural aos povos indígenas", com currículo, projeto pedagógico, material didático e formação específica de professores (BRASIL, 1996).

Nesse processo, Menezes e Santos (2001) descrevem que até o fim da década de 1980, no Brasil, a formação escolar, para crianças e jovens egressos das comunidades indígenas, esteve subordinada à perspectiva de integração ao processo de formação - político e cultural -, de um Estado Nacional, que tem em 
uma língua única, no caso o português, uma componente cultural central. As distintas tradições escolares que chegaram aos povos indígenas, na história do contato entre as populações nativas e os europeus e seus descendentes, desde as iniciativas dos pioneiros jesuítas, seguidos mais tarde por missionários de outras confissões religiosas, assim como no âmbito do Estado, pelo antigo SPI e, depois, pelas escolas da FUNAI, estiveram profundamente vinculadas ao integracionismo. Tais experiências escolares eram dirigidas por educadores não índios e seus currículos, processos pedagógicos, calendários e outros não deveriam se distinguir do paradigma da escola comum a que, em tese, a tem acesso qualquer brasileiro.

Segundo também a autora, a partir da LDB de 1996, o caráter da educação indígena foi mudado, visando a estimular uma educação intercultural. Para isso, foi criado, em 1998, o Referencial Curricular Nacional para as Escolas Indígenas (RCNEl) que apresenta noções básicas e sugestões de trabalho para o conjunto das áreas do conhecimento e para cada ciclo escolar das escolas indígenas inseridas no Ensino Fundamental (BRASIL, 1998). Ele se concretiza como um documento importante para esse tipo de educação escolar, uma vez que traz informações sobre os novos parâmetros, faz orientações curriculares e procedimentos pedagógicos em diversas áreas do saber, discute a atuação e a formação dos professores indígenas. Esse documento define quatro características da escola indígena: comunitária, intercultural, bilíngue/ multilíngue, específica e diferenciada.

De acordo com esse referencial, ela é comunitária porque é conduzida pela comunidade indígena de acordo com seus projetos, suas concepções e seus princípios; é intercultural porque deve reconhecer e manter a diversidade cultural e linguística; é bilíngue/multilíngue porque as tradições culturais, os conhecimentos acumulados, a educação das gerações mais novas, as crenças, o pensamento e a práticas religiosas, as representações simbólicas, a organização política, os projetos de futuro, enfim, a reprodução sociocultural das sociedades indígenas é, na maioria dos casos, manifestada por meio do uso de mais de uma língua; é específica e diferenciada "Porque é concebida e planejada como reflexo das aspirações particulares de cada povo indígena e com autonomia em relação a determinados aspectos que regem o funcionamento e orientação da escola não-indígena" (BRASIL, 1998, p. 25).

O referido documento foi elaborado por lideranças indígenas de todo o país, com especialistas da educação, antropólogos e professores, com vistas a 
Educação Indígena: escolarização e políticas...

transformar-se em um instrumento que auxilia, principalmente, professores indígenas e técnicos das Secretarias de Educação na implementação do projeto pedagógico e do currículo das escolas indígenas. No ano seguinte dessa publicação, foram aprovados o Parecer no 14 do Conselho Federal de Educação e a Resolução nº 003 da Câmara de Educação Básica, os quais instituíram as diretrizes curriculares nacionais para a educação escolar indígena e criaram a categoria "escola indígena".

Em 2001, foi aprovado o Plano Nacional de Educação (PNE), documento que apresentou um capítulo específico à educação escolar indígena, estabelecendo 21 objetivos e metas. Naquele período, o plano previu "criar, dentro de um ano, a categoria oficial de 'escola indígena' para que a especificidade do modelo de educação intercultural e bilíngue seja assegurada" (BRASIL, 2001). Além disso, o PNE determinou a instituição do magistério indígena, o estabelecimento de infraestrutura adequada e a criação de material didático específico, entre outros pontos. ${ }^{6}$

Nessas circunstâncias, no que tange ao ensino ao aluno indígena com deficiência, além de o professor conhecer as características individuais relacionadas à deficiência, ele deve conhecer a língua e cultura de seus alunos, para isso, esse professor deve ser indígena e da comunidade na qual ministrará aulas. A formação do professor índio torna-se mais complexa, à medida que ela deve atender uma educação bilíngue que valorize o patrimônio cultural de cada comunidade indígena e possa compreender as especificidades dos alunos com deficiência.

Sob esse prisma, Sá (2011) reitera que a formação inicial e continuada de professores indígenas para atuarem com alunos deficientes deverá ser discutida e construída dentro das comunidades indígenas, necessitará da participação de

\footnotetext{
${ }^{6}$ De acordo com Censo Escolar 2015 (IBGE, 2016), realizado pelo Ministério da Educação (MEC), cerca da metade das escolas indígenas tem material didático específico para o grupo. Especialistas em educação dizem que esse cenário é comum e que os indígenas raramente têm acesso a materiais em suas próprias línguas, os quais, geralmente, são elaborados por profissionais de outra etnia. O uso de material didático específico para os povos indígenas vem crescendo desde 2010 com algumas oscilações. Nesse ano, $50,5 \%$ das escolas trabalhavam com material específico; em 2013, o percentual passou para $56,7 \%$ e, em 2014 , houve uma ligeira queda, indo para $50,6 \%$ (IBGE, 2016). Nesse processo, os povos indígenas têm necessidades similares: querem produzir o seu próprio material didático, mas precisam de conhecimento técnico-científico para analisar a sua língua e definir qual será usada na escola. É do material externo que eles aprendem a língua portuguesa. O MEC explica que a oscilação da oferta de materiais didáticos específicos se deve ao aumento das escolas indígenas. O Ministério diz, ainda, que prioriza a preparação do material por autores indígenas e a produção em contextos de formação de professores indígenas no magistério intercultural. Entretanto, admite que a maioria dos materiais é elaborada para atender as séries iniciais do ensino fundamental, havendo uma grande lacuna para o ensino médio.
} 
alunos com deficiência, pais, professores e da comunidade geral, tendo em vista o desenvolvimento humano, a aprendizagem e autonomia moral e intelectual dos escolares com deficiência (BRASIL, 2010b).

Nesse caminhar, supõe-se que a formação de professores indígenas para o atendimento na área da educação especial encontra-se em "entre-lugares" e no contexto de novas identidades a serem negociadas. A presente pesquisa evidencia que uma política para esse tipo de formação é prioritária para a permanência com qualidade sociocultural das crianças indígenas com deficiência nas escolas indígenas. Trata-se de um padrão sociocultural que respeite as características e diretrizes da Educação Escolar Indígena. Portanto, novas políticas de formação do professor para o contexto da diversidade devem ser propostas e repensadas. São necessárias diretrizes capazes de articular a educação inclusiva e intercultural. Partindo-se das bases dos conceitos da corrente Estudos Culturais, conclui-se que é preciso respeitar as lógicas e as ressignificações dos processos de hibridação cultural e dos saberes indígenas. A formação de professores na área da educação especial indígena para as escolas indígenas constitui espaços fronteiriços (culturais e sociais) que interpelam o contexto educacional para sair em busca dos "entrelugares". Essa formação implica traduções inesgotáveis de significado para as escolas indígenas. Além de contribuir para o diálogo intercultural entre as políticas educacionais e para a gestão educacional. ${ }^{7}$

\section{EDUCAÇÃO ESPECIAL: trajetórias e consolidação}

Em toda a história da humanidade, dependendo do contexto social, pessoas ditas "diferentes" foram alvos de diferentes comportamentos. Desde seus períodos iniciais até os dias atuais, percebe-se que pessoas que apresentam quaisquer diferenças ou deficiências sempre são percebidas como sendo "diferentes" e sujeitas a vários estigmas ou rótulos. Nesse processo, podem ser identificados, em várias épocas e por diferentes povos, procedimentos e ações bem diversificados, que vão do extermínio ou marginalização, passando pelo assistencialismo piedoso e, mais recentemente, até a educação e a reabilitação voltadas a sua inclusão social e/ou educacional.

\footnotetext{
${ }^{7}$ Os dados do Censo Escolar 2006/MEC registra a atuação de 10.800 professores indígenas, representando mais de $90 \%$ dos docentes nas escolas das aldeias.
} 
Educação Indígena: escolarização e políticas...

Na pré-história, por exemplo, a sociedade primitiva era formada por povos nômades que viviam da caça e pesca e estavam sujeitos a manifestações climáticas, muito violentas, como tempestade, furações, inundações e seca. Isto dificultava o desenvolvimento e a aceitação de indivíduos que fugiam da rotina do seu dia a dia, sendo incapazes de irem buscar alimentação para sua tribo. Por esse motivo, eram abandonados em ambientes agressivos em que contribuíam a sua morte.

Segundo Amiralian (1986), nessa fase entendia-se a deficiência por meio de noções pré-científicas, nas quais prevaleciam valores culturais e éticos, sem uma explicação comprovada, estudada e/ou testada sobre os fatos. A trepanação (abertura de orifício no crânio), praticada pelo homem na Antiguidade, principalmente pelos egípcios, é uma manifestação dessa mentalidade. Por meio dessa técnica, buscava-se retirar os espíritos malignos do corpo da pessoa, procurando uma solução ou explicação para o problema. Ainda nessa concepção, os espartanos, um povo guerreiro que necessitava de homens fortes e saudáveis, eliminavam os "malformados e deficientes", pois estes não poderiam exercer suas funções na sociedade. Eram também jogados do alto do rochedo. Já em Atenas, eram abandonados em ambientes agrestes e perigosos e, entregues à própria sorte, morriam por inanição ou por ataque de animais selvagens. Entre os romanos, um povo mais tolerante, as pessoas com deficiências eram exibidas em festividades e comemorações em forma de infantilização e de diminuição de seu valor histórico e humano.

No entanto, foi no advento da Idade Média que a crença e as tentativas de explicar a deficiência mediante o sobrenatural se intensificaram. A prática da magia e as relações com o "demônio" fortaleceram-se como dogmas, e o homem passou a ser considerado um ser submetido a poderes invisíveis, tanto para o bem como para o mal. Em consequência disso, havia interpretações diferentes para os indivíduos considerados "anormais", dependendo do tipo de deficiência apresentada. Os psicóticos e epilépticos eram considerados possuídos pelo "demônio", alguns estados de transe eram aceitos como possessão divina e os cegos eram reverenciados como videntes, profetas e adivinhos (AMIRALIAN, 1986).

Com o estabelecimento do Cristianismo, as pessoas com deficiência começaram a ser vistas como possuidoras de alma e, portanto, filhas de Deus, não devendo mais ser exterminadas. O direito à vida lhes foi preservado e o 
descumprimento desse preceito era considerado um grande pecado. Assim, essas pessoas não eram mais abandonadas, mas acolhidas por instituições de caridade, ou seja, começaram a ser tiradas do isolamento total para serem alojadas em asilos e em instituições especializadas. Em geral, passaram a ser assistidas, mas continuavam segregadas em termos físicos, sociais e educacionais; passaram a ter direito à vida, em uma atitude de proteção, de filantropia, não sendo mais exterminadas. Ao mesmo tempo em que vigorava esse ideal cristão, contraditoriamente, pessoas com deficiência também eram consideradas produtos da união entre a mulher e o "demônio", o que justificava a queima da mãe e da criança (SCHWARTZMANN, 1999).

Ainda durante esse período, conforme registros encontrados, não havia obrigações nem moral nem social para com as crianças "anormais", que eram tratadas com indiferença, e a morte de um elevado número de crianças, inclusive das ditas normais, era encarada com naturalidade. As pessoas com deficiência eram alvo de diferentes e, por vezes, brutais formas de tratamento discriminatório, seja na infância ou na vida adulta, sobreviviam perambulando pelos campos e pelas cidades em busca de alimentos e de abrigo, mesmo que temporário. Com o passar do tempo, o assassinato, antes praticado, foi substituído pela segregação. Elas passaram a ser confinadas em casas, porões ou vales e, até mesmo, embarcadas em porões de navios (GAIO; MENEGHETTI, 2004).

Apesar de ser encontrado, com a propagação e a consolidação do Cristianismo, outro posicionamento em relação ao ser humano, mais justo e mais atencioso, no qual os valores da caridade, da fraternidade, da compaixão e do amor ao próximo elevaram a vida ao posto de direito adquirido de todo ser humano, normal ou anormal, dando final aos tempos de infanticídios e extermínio de pessoas com deficiência, não se pode afirmar que houve uma mudança radical e efetiva no conjunto da sociedade. O que predominou verdadeiramente, ao longo de todos esses anos, foi o desprezo, a negligência ou, quando muito, atitudes de tolerância a elas (GAIO; MENEGHETTI, 2004). Nos evangelhos, elas são fortemente relacionadas a castigos ou a penitências para expiação de faltas ou pecados. Havia a crença arraigada no povo de que esses males eram consequências da interferência de maus espíritos ou de castigo por pecados antigos.

Além disso, práticas, como punições, torturas e diversos tipos de maus-tratos, foram também usadas no lidar com essas pessoas (ARANHA, 1994). No contexto da 
Educação Indígena: escolarização e políticas...

Reforma, quando se passou a questionar e rejeitar os dogmas, as ações e o predomínio da Igreja Católica, pôde-se observar que seus representantes Lutero e Calvino também se referiam a essas pessoas como tendo possessões demoníacas, sem qualquer merecimento de atenção e de apoio. Ressalta-se que tais crenças e as práticas delas derivadas eram aceitas nessa época, pois se carecia de um conhecimento científico que explicasse o diferente. Enfim, até os séculos XVI e XVII, a mitologia, o espiritismo e a bruxaria dominaram e afetaram a visão que se tinha da deficiência e da pessoa com deficiência, dando origem a julgamentos morais, perseguições, encarceramentos, bem como informações distorcidas sobre a questão.

Para Silva (1987), essa longa etapa começou a ser superada com o Renascimento, época do aparecimento das primeiras reivindicações dos direitos dos homens postos à margem da sociedade, dos passos decisivos da medicina na área da cirurgia ortopédica, do estabelecimento de uma filosofia humanista mais voltada ao homem e, também, da consolidação de uma abordagem mais científica das questões relacionadas com o ser humano em geral. Além disso, a partir dessa fase, com a evolução e o advento da ciência, iniciaram-se estudos, em graus e intensidades variadas, nos diferentes ramos do saber, em todas as partes do mundo. No Renascimento, tentou-se entender o diferente por meio da pesquisa e, por isso, a ciência foi legitimada como via de explicação desses fenômenos que, até então, eram geralmente entendidos como manifestação do sobrenatural.

Em meados do século XVII, houve um novo período, cujas atitudes filosóficas e antropológicas se conjugaram promovendo uma perspectiva mais humanista da deficiência (FONSECA, 1987). Gaio e Meneghetti (2004) assinalam que, a partir de então, o conceito de deficiente e/ou diferente foi sendo construído lentamente na perspectiva de se atender aos interesses daqueles que eram apresentados como eficientes. Com o desenvolvimento da medicina, começaram-se a levantar objeções aos maus-tratos de que eram vítimas os "possessos", que passaram a ser considerados "doentes". A deficiência passou a ser vista como uma doença e suas manifestações físicas e comportamentos constituíam seus sintomas, levando a um diagnóstico em que o tratamento médico era o único procedimento a ser realizado. Tal ponto de vista prevaleceu por muito tempo e, até hoje, ainda percebem algumas heranças dessa cultura, quando a pessoa com deficiência é encarada como um 
doente e o médico, o elemento principal da equipe que o atende (AMIRALIAN, 1986).

Nesse período, já se pôde identificar o embrião da educação especial, dado o surgimento de algumas teorias e pesquisas, especificamente as relativas à saúde e à educação. Os trabalhos de Rousseau (1712-1778) foram fundamentais para a mudança de paradigma no campo da educação em geral, mas também para se poderem encaminhar estudos sobre a educação especial, ao enfatizar a necessidade de se compreender a criança em suas especificidades.

Lancelotti (2000) assinala que a educação especial, nas sociedades industriais no século XVIII, emergiu como parte pouco significativa de um conjunto de reivindicações de acesso à riqueza produzida (material e cultural) e que desembocou na construção da democracia republicana representativa, cujo modelo expressivo foi implantado na França, pela revolução de 1789:

[...] o acesso à escolarização dos deficientes foi sendo conquistado ao mesmo tempo em que se conquistava este mesmo acesso para as crianças em geral. Em outras palavras, a história nos mostra que a educação especial não nasceu para dar oportunidade a crianças que, por anormalidades específicas, apresentavam dificuldades na escola regular. A educação especial nasceu voltada para a oferta de escolarização de crianças cujas anormalidades foram aprioristicamente determinadas como prejudicais ou impeditivas para sua inserção em processos regulares de ensino. E esta não é uma mera diferença de ênfase na análise do percurso histórico da educação especial, mas uma diferença de fundo, demonstrativa do caráter de segregação do indivíduo anormal e dos processos exigidos pelas novas formas de organização social. (BUENO, 1993, p. 37).

Porém, no século IX, é que se expandem os estudos científicos da deficiência, principalmente, a mental. Nesse período, devem-se destacar pelo seu interesse global, os trabalhos de Esquirol, Séguin, Itard, Wundt, Ireland, Ducan e Millard, Morel, Lombroso, Down, Galton, Tuke, Rush e Dix, entre outros (FONSECA, 1987). Os estudos científicos permitiram que, no plano prático, mecanismos passassem a ser amplamente utilizados para triar quem deveria ou não se beneficiar da escolaridade regular (MENDES, 2003). Nessa perspectiva, também, no século XVII, dois importantíssimos intelectuais surgiram, o médico Paracelso e Cardano, filósofo. Paracelso escreveu o livro Sobre as Doenças que privam o Homem da Razão, e foi o primeiro a considerar a deficiência mental como um problema médico, digno de tratamento e complacência. Também Cardano acreditava que a deficiência era um problema médico e preocupava com a educação das pessoas que apresentavam a deficiência. Nessa fase, novas leis foram surgindo e definindo a 
Educação Indígena: escolarização e políticas...

loucura e a idiotia como disfunções, com o objetivo de administrar a herança dessas pessoas.

Nesse mesmo período, John Lockes revolucionou as leis vigentes sobre a mente humana e suas funções, sua definição para recém-nascido e o idiota como tabula rasa, porém defendia que o ensino supria essa carência da pessoa com deficiência.

Mais adiante, na Idade Contemporânea, no século XIX, o autor Jean-Jacquea Gaspar Itard apresentou o primeiro programa sistemático de educação especial (1800), apresentando uma metodologia que usou com o filho adotado, Victor, o Selvam de Aveyron.

Em setembro de 1799, um menino, de cerca de 12 anos de idade, foi encontrado perto da floresta de Aveyron, sul da França. Estava sozinho, sem roupa, andava de quatro e não falava uma palavra. Aparentemente fora abandonado pelos pais e cresceu sozinho na floresta. O jovem médico Jean-Jacques Gaspar Itard encontrou um aglomerado de pessoas observando o menino enjaulado, a quem chamavam de menino-macaco. Com autorização judicial, o médico o conduziu à sua residência, onde se propôs a tratá-lo e educá-lo, tornando-o objeto de investigações científicas. Aparentando seis a oito anos de idade, surdo e mudo, com posturas próximas do animalesco, o menino que fora capturado no mato, onde teria sido abandonado ainda recém-nascido, quase nada aprendeu. Itard observou meticulosamente o menino durante três anos, período que teve de sobrevida em ambiente social. Entre as letras do alfabeto fonético, o menino aprendeu apenas a pronunciar o "ô", derivando daí o nome Victor e o sobrenome d'Aveyron, região onde foi capturado. Durante este período, o máximo de imagens que Victor conseguiu reconhecer foi o desenho de uma garrafa de leite no quadro negro. Itard levantou comportamentos e reações de Victor, relacionou-os e fez descobertas importantes, como as relações fisiológicas entre garganta, nariz, olhos e ouvidos. Assim, criou a otorrinolaringologia. Foi o fundador da Psicologia Moderna e da Educação Especial; forneceu importantíssimos elementos para o estudo do significado das aquisições culturais ao funcionamento da inteligência humana. Em outras palavras, para a dicotomia natureza $x$ cultura. Ao final do trabalho, Victor não era mais o menino selvagem de quando fora encontrado, mas, também, não se tornou, de acordo com os parâmetros da época, humano. (RODRIGUES, 2008, p. 12).

Nos referidos estudos, conforme o conceito retratado por Itard, a idiotia era compreendida pela pouca bagagem cultural; já para Pinel, era uma deficiência biológica. No entanto, existe muita discordância entre esses dois autores até hoje. Apesar da grande evolução pedagógica e da filosofia, o trabalho do Itard não previne nem cura a deficiência mental. Com essa influência, começaram a surgir as primeiras escolas para criança com deficiência mental. Nesse sentido, o trabalho educativo com essa clientela foi se ampliando e exigindo mudanças das atitudes para, posteriormente, se mudarem as ações. 
Ao aproximar-se do século $\mathrm{XX}$, apareceram as escolas especializadas, sobretudo em países industrializados e, depois, nos demais. A existência de pessoas com deficiências exigiu a melhoria da ação educativa, o que levou à elaboração de programas, de métodos e de serviços diferenciados para cada especificidade de alunado, e, com isso, à criação de um sistema educativo paralelo. Paulatinamente, dentro da instituição especializada, as classificações ou as avaliações vão ocorrendo em torno do défice do aluno. Ao longo desse século, as ciências contribuíram para uma nova compreensão da ação humana, do corpo, do trabalho, do lazer e do processo de aprendizagem. Buscou-se, também, o entendimento do ser humano considerado como pessoa com deficiência na perspectiva da superação do estigma da deficiência e da sua reconceituação (GAIO; MENEGHETTI, 2004).

Quanto às propostas pedagógicas destinadas aos alunos com deficiências, verifica-se que não estavam desvinculadas da educação geral, até o século $X X$, quando Decroly apresentou sua proposta, considerada inovadora para a época, pois se baseou nos princípios da Gestalt, propondo o método de globalização que introduziu a ideia dos centros de interesse. Desde então, foi formulada uma maneira de conduzir o ensino, levando o professor a considerar os ritmos e interesses diferenciados dos seus alunos.

\subsection{Criação e implementação de serviços, atendimentos e estudos relacionados à educação especial}

Nessa evolução, observou-se também o surgimento dos primeiros trabalhos na Europa, mais precisamente na França, em $1620^{\circ}$. No final do século XVII, surgiu, na Alemanha, um método revolucionário que pretendia facilitar a aprendizagem de "surdos-mudos", buscando ensinar-Ihes a ler e a escrever. Na cidade de Paris, em 1770, foi criado o primeiro Instituto Especializado para Educação de Surdos-Mudos e o primeiro Instituto Nacional dos Jovens Cegos (CADERNOS CEDES, 1985).

Em Londres (Liverpool), foi implementada, em 1799, uma escola com um trabalho especificamente voltado ao ensino de pessoas com qualquer tipo de deficiência. Já em 1832, surge a primeira obra destinada ao atendimento de pessoas com deficiência física, que, na época, eram designados "coxos, mancos ou

\footnotetext{
${ }^{8} \mathrm{Em}$ 1620, Pablo Bonet publicou o livro Reeducação de Letras e Artes para Ensinar a Falar os Surdos (ANACHE, 2003).
} 
Educação Indígena: escolarização e políticas...

paralíticos". Na primeira metade do século XIX, surgiu o primeiro Internato Público para "retardados mentais", por iniciativa do Dr. Jean Marc Itard e levado à frente pelos seus seguidores. Nessa instituição, buscava-se ensinar, mediante materiais didáticos especiais, aproveitamento de cores, formas, espaços e música para motivar e alegrar as crianças.

Além de Comênio, que em sua obra, a Didática Magna (1657), dedicou uma parte à educação de indivíduos considerados idiotas, outros educadores também se propuseram a realizar estudos sobre a educação especial, como Pestalozzi (17461827) e Froebel (1782-1852). Deu-se um enfoque especial ao jogo como recurso didático empregado para educar os sentidos dos estudantes. Além desses, foi Charles-Michel de l'Epée (1712-1789) quem criou a primeira escola pública de Paris e introduziu o método oral.

Nos Estados Unidos, escolas para cegos, surdos e "retardados mentais" começaram a proliferar entre 1817 e 1850. Os programas para crianças com defeitos físicos surgiram posteriormente. Entre 1850 e 1870, verificou-se um efetivo crescimento de escolas residenciais, nesse país, sob a influência do modelo europeu. Essas escolas começaram a ser então concebidas como instituições tutelares para crianças e adultos sem esperança de vida independente e sem possibilidade educacional. Desde então, os programas de externato foram iniciados. A primeira classe especial diária para "retardados mentais", em período integral, foi aberta em 1896, em Previdence, Rhode Island. A primeira classe para cegos e a primeira para "crianças com deficiência", em uma escola pública, foram abertas em Chicago, em 1900, quando houve grande incremento de classes especiais para crianças com deficiência física, sensorial e mental em todos os continentes.

Em 1819, na França, Charles Barbier, oficial do exército desse país, criou um sistema baseado no processo de escrita codificada e expressa por pontos salientes, representando os 36 sons básicos da língua francesa utilizada para a transmissão noturna de mensagens nos campos de batalha. Em 1829, o jovem cego Louis Braille adaptou o código militar às necessidades dos cegos, transformando-o no conhecido sistema que recebeu seu nome (ESCOLA PLURAL, 2000).

Edmund Seguin (1812-1880) desenvolveu, na França e, mais tarde, nos Estados Unidos, o método fisiológico de tratamento e o treino sensório-motor que se tornaram métodos clássicos de intervenção em muitas escolas e instituições de pessoas com deficiência mental, só continuados, posteriormente, no século XX, pela 
escola sensorial de Montessori (FONSECA, 1987). Em 1940, nos Estados Unidos, surgiu a primeira associação organizada por pais de crianças com paralisia cerebral, visando a angariar fundos para centros de tratamento, pesquisas e treinamento profissional. Em 1950, os pais das crianças com deficiência mental organizaram-se em defesa dos interesses e das necessidades de seus filhos, criando a National Association for Retarded Children (NARC), que exerceu grande influência em vários países, inclusive no Brasil, onde inspirou a criação da Associação de Pais e Amigos dos Excepcionais (APAE).

As pessoas com deficiência, vistas como "não desejadas" e "nada atraentes fisicamente", viveram encerradas, durante quase todo o século XIX, em instituições como "prisão", autênticos "guetos", depósitos e reservas de segregados. De 1900 a década de 1970, o movimento da escola pública criou as denominadas classes de "anormais", fase que se iniciou com a categorização e a classificação das pessoas com deficiência mental mediante a aplicação da famosa Escala Métrica de Inteligência, criada por Binet e Simon em 1905 (FONSECA, 1987). Nessa fase, expandiram-se alternativas pedagógicas que objetivavam reduzir a segregação, tais como o atendimento em classes denominadas especiais nas escolas do sistema regular de ensino (PESSOTTI, 1994; JANNUZZI, 1992; CARVALHO, 1991).

A fase atual caracteriza-se por modificações profundas, expressas nas políticas que regem o atendimento às pessoas com deficiências, no sentido de superar as noções preconcebidas e estigmas existentes, bem como de intensificar a participação delas na escola e na sociedade em geral. Segundo essa nova perspectiva, incluir não significa "tornar o indivíduo normal", concepção que persistiu durante algum tempo, mas consiste em proporcionar a tais pessoas as condições de vida similares às das outras e possibilidades de uma vida tão normal quanto possível, assegurando-lhes o acesso aos bens sociais (educação, saúde, trabalho, lazer), políticos, culturais e econômico.

Nesse panorama, a educação especial constituiu-se originalmente de um modelo médico ou clínico. Embora essa abordagem seja hoje bastante criticada, é preciso resgatar que os médicos foram os primeiros a despertar para a necessidade de escolarização de indivíduos com deficiência que se encontravam misturados na população dos hospitais psiquiátricos, sem distinção de patologia ou de idade, principalmente no caso da deficiência mental. 
Educação Indígena: escolarização e políticas...

Sob esse enfoque, o olhar médico tinha precedência: a deficiência era entendida como uma doença crônica e todo o atendimento prestado a essa clientela, mesmo quando envolvia a área educacional, era considerado pelo viés terapêutico. A avaliação e identificação eram pautadas em exames médicos e psicológicos com ênfase nos testes projetivos e de inteligência, e rígida classificação etiológica.

Nesse momento até a década de 1960, os métodos educacionais utilizados para atender aos alunos com deficiências eram voltados para crianças e jovens impedidos de acessar a escola comum do ensino regular ou para aqueles retirados das classes comuns por não avançarem no processo educacional. Essa segregação era realizada sob o argumento de que tais alunos seriam mais bem atendidos se fossem encaminhados para classes ou escolas especiais.

A educação especial foi, então, se constituindo em um sistema paralelo ao geral, até que, por motivos morais, lógicos, científicos, políticos, econômicos e legais, surgiram as bases para reivindicar e fundamentar as práticas de integração na escola regular (MENDES, 2003). Esses interesses, em geral, foram atendidos em diferentes países com o estabelecimento de bases legais que instituíram, gradualmente, a obrigatoriedade do poder público quanto à oferta de oportunidades educacionais a tais indivíduos, mediante a instituição da matrícula compulsória nas escolas regulares e de diretrizes para a colocação desses alunos em serviços educacionais com o mínimo possível de segregação.

Dessa forma, estavam estabelecidas as bases para o surgimento da filosofia da normalização e da integração escolar, que se tornou ideologia dominante para a prestação de serviços educacionais, basicamente, a partir da década de 1970. Escolas regulares passaram, assim, a aceitar crianças ou adolescentes com deficiência em classes comuns, ou, pelo menos, em classes especiais ou de recursos. A integração escolar era concebida como um processo com vários níveis, por meio do qual o sistema educacional proveria os meios mais adequados para atender às necessidades dos alunos. O nível mais apropriado seria aquele que melhor favorecesse o desenvolvimento de determinado aluno, em determinado contexto e momento (MENDES, 2003).

As políticas oficiais de integração escolar resultaram, na maioria das vezes, em práticas quase que permanentes de segregação total ou parcial, o que acabou gerando reações mais intensas no sentido de buscar novas formas de assegurar a presença e a participação na comunidade, a promoção de habilidades, da imagem 
Jucélia Linhares Granemann de Medeiros | Sonia Grubits

social, da autonomia e da autodeterminação das pessoas com deficiências (MENDES, 2003).

Grozada (2010) acrescenta que, no Brasil, os anos de 1970 representaram a institucionalização da educação especial, com a preocupação do sistema educacional público em garantir o acesso à escola aos alunos com deficiências. Em 1973, foi criado, no Ministério da Educação, o Centro Nacional de Educação Especial (CENESP) (transformado em 1986 na Secretaria de Educação Especial SEESP), que introduziu a educação especial no planejamento das políticas públicas educacionais.

Por iniciativa do CENESP, foram implantados subsistemas de educação especial nas diversas redes públicas de ensino com a criação de escolas e classes especiais. Também sob os auspícios desse órgão, foram implementados projetos de formação de recursos humanos especializados em todos os níveis, inclusive com o envio de docentes para cursos de pós-graduação no exterior, o que permitiu o desenvolvimento acadêmico e científico da área.

Todavia, apesar dos avanços, a educação especial manteve-se funcionando como um serviço especializado paralelo: com currículos, metodologias, pessoal e organização própria. As classes especiais serviam mais como espaços de segregação para aqueles que não se enquadravam nas normas do ensino regular, do que uma possibilidade de ingresso de alunos com deficiências nas classes comuns.

Consequentemente, a maioria desses continuava frequentando instituições especializadas ou encontrava-se fora da escola. Paralelamente, observou-se, nessa fase, que os recursos e métodos de ensino mais eficazes proporcionaram às pessoas com deficiências mais condições de adaptação social, auxiliando a superar, pelo menos em parte, as dificuldades cotidianas. Acompanhando a tendência mundial da luta contra a marginalização das minorias excluídas, começaram-se a divulgar e a consolidar, no Brasil, os princípios que nortearam a filosofia da normalização.

De modo geral, essa concepção de educação especial partia da premissa básica de que pessoas com deficiências têm o direito de usufruir as condições de vida o mais comum ou normal possível na sua comunidade, participando das mesmas atividades sociais, educacionais e de lazer que os demais. É importante ressaltar que a proposta não era, como erroneamente criticada, "normalizar a 
Educação Indígena: escolarização e políticas...

pessoa com deficiência", mas sim normalizar as condições de vida, ou melhor, trazer para o mais próximo possível do comumente usado pelos demais indivíduos da população.

Nessa apontar, o "deficiente pode se integrar na sociedade" tornou-se, assim, a matriz política, filosófica e científica da educação especial. Esse novo pensar sobre o espaço social das pessoas com deficiências tomou força no Brasil com o processo de redemocratização, e resultou em um redirecionamento significativo das políticas públicas, dos objetivos e da qualidade dos serviços de atendimento a essa população, marcando o desenvolvimento da área até os dias atuais.

Nessa evolução, a educação especial, tradicionalmente, configurou-se como um sistema paralelo e segregado de ensino, voltado para o atendimento especializado de indivíduos com deficiências, distúrbios graves de aprendizagem e/ou de comportamento, e altas habilidades.

$\mathrm{Na}$ maioria das instituições especializadas (pública ou de iniciativa da sociedade civil), o trabalho era organizado com base em um conjunto de terapias individuais coordenadas pela medicina: fisioterapia, fonoaudiologia, psicologia, psicopedagogia, terapia ocupacional, entre outras. Pouca ênfase era dada à atividade acadêmica, que não ocupava mais do que uma pequena fração do horário dos alunos. A educação escolar não era considerada prioritária, ou mesmo possível, principalmente para aqueles com deficiências cognitivas, múltiplas, ou distúrbios emocionais severos. O trabalho educacional era voltado para a autonomia nas atividades de vida diária (AVD) e relegado a um interminável processo de "prontidão para a alfabetização", sem muitas perspectivas, já que não havia expectativas de que esses indivíduos ingressassem na cultura letrada formal.

Mais à frente, em um processo de redirecionamento, tais estratégias e práticas tradicionais da educação especial passaram a ser questionadas, desencadeando a busca por alternativas pedagógicas menos segregadas, oficializadas nas políticas públicas nacionais e internacionais. A Constituição federal, por exemplo, no artigo 208, como em legislação subsequente, recomenda a inserção dos alunos com deficiência preferencialmente no sistema regular de ensino (BRASIL, 1999).

Sob essa ótica, ressalta Bueno (2001), o problema continua centrado no aluno e no ensino especial, já que a escola regular caberia apenas educar aquele com condições de acompanhar as atividades rotineiras, concebidas em qualquer 
preocupação com as necessidades individuais. Em outras palavras, eram "exilados" para classes especiais, alunos com dificuldades de adaptação às exigências de uma escola cujas práticas eram desvinculadas da realidade social na qual estava inserida. Embora os professores especializados enfatizassem seu papel no suporte ao desenvolvimento de atividades específicas da área da deficiência e rejeitassem a tarefa de reforço dos conteúdos do desenvolvimento nas turmas comuns, na maioria dos casos, a escola tradicional acabava delegando a responsabilidade, pelas aprendizagens desses alunos, exclusivamente ao professor da sala de recursos.

Atentando para o início da década de 1990, percebe-se uma intensificação do debate sobre a integração, com novos questionamentos sobre o papel da escola diante da diferença, dando ênfase à necessidade de fusão dos sistemas especiais e regulares. Foi, assim, substituída a ideia de educação visando à homogeneidade para a de educação voltada à diversidade, e, no ensino especial, houve a mudança no foco da educação como categorial para a ênfase no conjunto de recursos/apoios/suportes a serem oferecidos aos alunos com deficiências ${ }^{9}$.

Nesse processo, o movimento dos direitos das pessoas com portadora de deficiência teve uma grande participação, sendo que, segundo Bueno (2001), todas as mudanças que gradativamente foram ocorrendo provocaram um novo processo, voltado para a conscientização social, consequência de movimentos e reivindicações iniciadas na década de 1970 e intensificadas nos anos de 1980. Desde essa data, estabeleceu-se o Ano Internacional das Pessoas Deficientes (AIPD) incentivado pela ONU.

Nessa vertente, vê-se que, nas últimas décadas, em função de demandas e expectativas sociais, aliadas aos avanços das ciências tecnológicas, os profissionais da educação especial têm se voltado para a busca de outras formas de educação escolar com alternativas menos segregativas de absorção desses educandos nas redes de ensino. Dessa forma, vem se buscando, recriar a escola para que ela seja

\footnotetext{
${ }^{9}$ No Dicionário Houaiss (2018), deficiência se caracteriza por 1. insuficiência ou ausência de funcionamento de um órgão, 2. insuficiência de uma função psíquica ou intelectual. Sendo assim pode-se considerar que a pessoa com deficiência é aquela que apresenta, em caráter permanente, perdas ou reduções de sua estrutura, ou função anatômica, fisiológica, psicológica ou mental, que gerem incapacidade para certas atividades, dentro do padrão considerado normal para o ser humano. A definição de "criança deficiente" aceita internacionalmente, aprovada pela Council of Exceptional Children (CEC), é, segundo Fonseca (1987), a criança que se desvia da média ou da criança normal em: características mentais; aptidões sensoriais; características neuromusculares e corporais; comportamento emocional; aptidões de comunicação; múltiplas deficiências, até justificar e requerer modificação das práticas educacionais ou a criação de serviços de educação especial no sentido de desenvolver ao máximo as suas capacidades.
} 
Educação Indígena: escolarização e políticas...

porta de entrada das novas gerações para o mundo plural em que vivemos. Assim, poderá auxiliar nas reformas educacionais e em todas as tentativas de se repensar a prática pedagógica sempre em vista da ética, da justiça e dos direitos humanos. Esse tripé precisa vencer a exclusão, a competição ou o egocentrismo, em busca de uma nova fase de humanização e de socialização, vindo, então a superar barreiras físicas, psicológicas, especiais, temporais, culturais. Na verdade, escolas devem ser contextos educacionais capazes de ensinar a todos, em uma mesma turma, sem excluir ninguém de qualquer atividade, tendo em mente que toda criança sempre sabe alguma coisa.

Com a proposta de integração das pessoas com deficiência, na década de 1960, a Lei de Diretrizes e Bases da Educação Nacional (Lei n. 4.024/1961) reafirma o direito à educação dessas pessoas, indica em seu art. 88 que, para integrá-las na comunidade, sua educação deverá, dentro do possível, enquadrar-se no sistema geral de educação (BRASIL, 1961). Nessa perspectiva, a Lei no (BRASIL, 1971), referente a Diretrizes e Bases para ensino de $1^{\circ}$ e $2^{\circ}$ graus, no art. $9^{\circ}$, veio assegurar tratamento especial aos alunos que apresentem deficiências físicas ou mentais (MAZZOTTA, 2005).

No final da década de 1980, com a promulgação da Constituição Federal de 1988 (BRASIL, 1999), observa-se ampliação significativa de leis e políticas referente à educação das pessoas com deficiência. Destaca-se o direito público subjetivo à educação de todos, inclusive daqueles com algum tipo de deficiência, preferencialmente, na rede regular de ensino. Estabelece como princípios para o ensino: a igualdade de condições de acesso e permanência na escola; o dever do Estado de garantir o acesso aos níveis mais elevados do ensino; a oferta do Atendimento Educacional Especializado (BRASIL, 1999, arts. 205, 206, 208).

A partir da década de 1990, as propostas políticas para a educação especial procuraram atender as indicações de movimentos internacionais que visavam uma perspectiva inclusiva. Assim, as políticas educacionais brasileiras incorporaram as orientações internacionais tratadas na Conferência Mundial de Educação para Todos (JOMTIEN, 1990) e na Declaração de Salamanca, de 1994 (BRASIL, 1997). No que diz respeito à Declaração Mundial sobre Educação para Todos (JOMTIEN, 1990), esta ressalta a educação como direito social e a necessidade dos Estados partes tomarem medidas para a garantia da igualdade de oportunidades às minorias 
sociais, linguísticas e às pessoas com deficiência, quanto ao acesso e à promoção da aprendizagem nos diferentes níveis de ensino.

A Declaração de Salamanca (BRASIL, 1997) trouxe transformações significativas referente aos objetivos da educação especial, uma vez que recomenda a inclusão no ensino regular de todas as crianças com deficiência. Preconiza que as escolas inclusivas devam reconhecer e responder às necessidades específicas de seus alunos e aponta para a necessidade de existir uma continuidade de serviços e apoio proporcional às necessidades especiais encontradas dentro da escola regular. Observa-se que a educação especial, que por muito tempo se constituiu paralela ao sistema de ensino regular, está sendo obrigada a redimensionar o seu papel, antes restrito ao atendimento direto dos alunos com deficiência, para atuar, prioritariamente, como suporte à escola regular no recebimento desse alunado (PLETSCH; FONTES; GLAT, 2006, p. 3).

Nessa perspectiva, nas políticas educacionais brasileiras, a educação especial passa a ser identificada como uma modalidade de educação a ser ofertada, preferencialmente, na rede regular de ensino, a partir da educação infantil. Assim, a LDB/1996 determina que o acesso à educação das pessoas com deficiência deve iniciar na educação infantil e ir até o ensino superior. Traz um novo conceito de educação especial, definida como modalidade transversal que perpassa todos os níveis de ensino. Preconiza que os sistemas de ensino deverão assegurar aos alunos com deficiência "[...] currículos, métodos, técnicas, recursos educativos e organização específica para atender às suas necessidades" (BRASIL, 1996, arts. 58-59).

Na Política Nacional de Educação Especial na Perspectiva da Educação Inclusiva (BRASIL, 2008c), a educação especial constitui uma modalidade de ensino que perpassa todos os níveis, etapas e modalidades, realiza 0 atendimento educacional especializado (AEE), identifica as necessidades educacionais especiais, disponibiliza os serviços e recursos próprios desse atendimento e orienta os alunos e seus professores quanto a sua utilização nas salas comuns do ensino regular.

Nessa ótica, a Política Nacional da Educação Especial traz como finalidade dessa interface "[...] assegurar que os recursos, serviços e atendimentos educacionais especializados estejam presentes nos projetos pedagógicos construídos com base nas diferenças socioculturais desses grupos" (BRASIL, 2008c,

p. 22-23). O AEE constitui um serviço de apoio especializado aos alunos com 
Educação Indígena: escolarização e políticas...

deficiência (BRASIL, 2011b). Esse serviço compreende um "[...] conjunto de atividades, recursos de acessibilidade e pedagógicos organizados institucional e

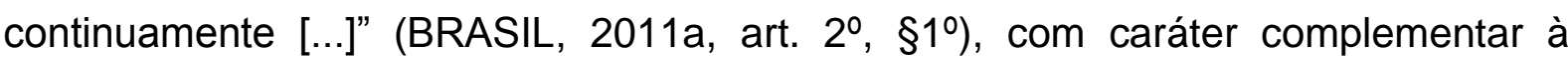
formação dos estudantes com deficiência e transtornos globais do desenvolvimento, bem como um serviço suplementar à formação de estudantes com altas habilidades ou superdotação (BRASIL, 2011a). O AEE realizado nas salas de recursos multifuncionais (SRMs) deve se integrar à proposta pedagógica da escola, envolver a participação da família e articular-se com as demais políticas públicas. As pesquisas sobre a implementação do AEE.

A interface entre a educação especial e a educação indígena também foi contemplada na versão final do documento da Conferência Nacional de Educação (CONAE). No eixo VI, destinado a "Justiça Social, Educação e Trabalho: Inclusão, Diversidade e lgualdade" é mencionado a necessidade de se construir a interface da educação especial com a educação escolar indígena. No item destinado a educação indígena, o documento propõe que as políticas deverão "Estimular a interface da educação especial na educação indígena, assegurando que os recursos, serviços e AEE estejam presentes nos projetos pedagógicos, construídos com base nas diferenças socioculturais desses grupos" (BRASIL, 2010a, p. 141).

No Plano Nacional de Educação (2011-2020), em tramitação no Congresso Nacional, em sua Meta 4, destinada a "Universalizar para a população de 4 a 17 anos, o atendimento escolar aos estudantes com deficiência na rede regular de ensino", no item 4.2 é apontando como meta "Implantar salas de recursos multifuncionais e fomentar a formação continuada de professores para o atendimento educacional especializado complementar, nas escolas urbanas e rurais" (ressalta-se que as escolas indígenas situam-se na zona rural).

Ao se atentar ao Censo Escolar da Educação Básica verifica-se que nas escolas indígenas vem aumentando o número de alunos com deficiência matriculados. Em geral, segundo dados de 2010 (861 matrículas) com o ano base de 2007 (589 matrículas), observou-se um aumento de 46\% desse alunado nas escolas indígenas. Em 2007 existiam 1.161 matrículas, porém em 2010 esse número era de 2.403 , houve um aumento de $107 \%$ do número de matrículas desse alunado. Por meio dos dados coletados no Censo Escolar, pode-se observar que uma nova realidade se apresenta para as escolas indígenas, sendo que a cada ano aumenta o número de matrículas de alunos com deficiência. $\mathrm{E}$ o desafio que se 
coloca para estas escolas é educar esses alunos dentro da cultura e atender as especificidades de cada deficiência.

Outro dado relevante, parte do censo escolar (BRASIL, 2008b; 2009; 2010c; 2011a; 2012c), em média, 1,7\% do total das matrículas da educação básica no Brasil corresponde a alunos com deficiências. Ao analisarmos cada área específica do campo, constata-se que a maior concentração das matrículas de alunos com deficiências que vivem e estudam no campo está em áreas rurais, seguida, respectivamente, pela área de assentamento e terra indígena. As matrículas de alunos com deficiências em área de assentamento representam 5,7\% do total de alunos com deficiências que vivem e estudam no campo. Ao analisarmos o período de 2008 a 2012, percebe-se um aumento expressivo (116,6\%) no número de matrículas de alunos com deficiências em escolas de assentamento. Esse acréscimo, possivelmente, pode estar associado às conquistas legais que os povos indígenas apresentaram nas políticas nacionais, as quais, hoje, garantem o reconhecimento cultural desses povos e escolas diferenciadas dentro de seus territórios (BRASIL, 1988; 1996; 2012a).

Nessa interlocução, a interface da educação especial na educação indígena assegura que os recursos, serviços e atendimento educacional especializado sejam contemplados nos projetos pedagógicos construídos com base nas diferenças socioculturais desses grupos. Este documento trouxe avanços referentes ao serviço, recursos e ao atendimento educacional especializado, porém, deixa alguns questionamentos: Quem será o profissional que atuará na educação especial dentro dessas comunidades? Como será efetivada sua formação inicial e continuada? Como serão avaliados esses alunos? Como as equipes de saúde entendem e intervêm com essa clientela? Na escola, os alunos com deficiências estão sendo recebidos. Como são trabalhados? Quais suas principais dificuldades ou lacunas? Como estão sendo produzidos os materiais/livros destinados a esse alunado? entre outras questões.

No que se refere à formação dos professores na área de educação especial, observa-se que esta está comprometida também porque sua habilitação em educação especial nos cursos de Licenciatura em Pedagogia foi retirada no cenário educacional pela Resolução CNE/CP n 1, de 15 de maio de 2006, em seu art. 10 (BRASIL, 2006). A partir dela, a Licenciatura em Pedagogia passa a formar professores para "[...] exercerem funções de magistério na Educação Infantil e nos 
Educação Indígena: escolarização e políticas...

anos iniciais do Ensino Fundamental, nos cursos de Ensino Médio, na modalidade Normal, de Educação Profissional na área de serviços e apoio escolar e em outras áreas [...]" (BRASIL, 2006, art. $\left.4^{\circ}\right)$. Na interface da educação especial com a educação escolar indígena, torna-se ainda mais emblemático, verifica-se que, não há diretrizes específicas para a formação de professores indígenas na educação especial, como se pode ver no Parecer nำ 13/2012 (BRASIL, 2012a), Resolução no 5/2012 (BRASIL, 2012b), Referenciais para a Formação de Professores Indígenas (RFPI) (BRASIL, 2002) e o RCNEI (BRASIL, 1998).

Partindo desse pressuposto, percebe-se que é preciso compreender também as modalidades de educação especial e de educação indígena (entre outras), para que o professor seja qualificado para atuar nesses âmbitos. Geralmente, os cursos têm apenas certificado os professores com conhecimentos básicos, não potencializando áreas específicas. Quase sempre, os próprios docentes precisam aprimorar os seus conhecimentos específicos em futuras especializações ou em cursos de aperfeiçoamento.

Nóvoa (1997) ensina que a formação não se constrói por acumulação de cursos, mas por meio do trabalho de reflexividade crítica sobre as práticas e reconstrução permanente de uma identidade pessoal. Assim, a formação docente e as experiências do trabalho corroboram na percepção da sua profissão, contribuindo para que se realize dentro da escola um trabalho diferenciado, com professores que efetivamente consigam responder às necessidades de todas as crianças diante de suas deficiências e/ou limitações.

\section{CONSIDERAÇÕES FINAIS}

Nessa trajetória, a escola, se tornará um espaço de diálogo, de trocas, que abrigará uma significativa diversidade composta de diferenças de todas as ordens como hábitos, origens, concepções, formação, religião, cultura..., relevando-se a importância da discussão sobre o respeito à diferença, ao outro, de forma a fazer da heterogeneidade que a compõe um aprendizado recíproco. Ou seja, compreender a diferença como um valor, porque "[...] a diferença não é só compatível com o ser humano, mas é sua própria condição" (URQUIZA, 2004, p. 297).

Dessa forma, a ênfase que se observa, no âmbito das mudanças no cenário educacional, para a oferta de uma educação intercultural justifica-se, ao lado de seu 
caráter inadiável, para a adequação da escola às exigências que se impõem perante a realidade globalizada. Tal situação, entretanto, sugere que se não se perca de vista se o modelo de educação intercultural, presente nos textos legais e institucionais, será capaz de alcançar os objetivos a que se propõem. Com uma tradição tão voltada à homogeneidade, há de se considerar o modelo de escola que se quer construir, atento para os limites que tal modelo possa vir a revelar. Os limites inserem-se na consciência de que a implementação de propostas, bem como a homologação de leis que assegurem o reconhecimento das diferenças, não garantem, por si só, a mudança de valores no espaço escolar.

Há de se considerar que há todo um contexto, que passa pela organização do currículo, pela definição da filosofia norteadora da escola e pela consideração de seu entorno. O conceito de diferença, então, voltado para a realidade dos povos indígenas e suas conquistas em relação à escola, induz a reflexões a fim de evidenciar a relevância da diferença, a compreensão sobre esse conceito, sobretudo ao ponto que essa (a diferença) eclode no espaço escolar.

Nesse cenário, de acordo com Sá (2011) e Souza (2011), caberá, portanto, investigar como essa interface vem sendo implementada no contexto das escolas indígenas brasileiras, pois estudos que se têm na área indicam precariedades entre a legislação e as políticas implementadas, principalmente no que se refere ao acesso, permanência e qualidade do ensino destinado a alunos indígenas com deficiência nas escolas. Processo este, de relevância inigualável, no sentido da abertura e cumprimento de direitos a essa população tão discriminada e na realidade, pouco atendida. 
Educação Indígena: escolarização e políticas...

\section{REFERÊNCIAS}

AMIRALIAN, M. L. T. M. Temas básicos de psicologia. In: RAPPAPORT, C. R. (Coord.). Psicologia do excepcional. São Paulo: Editora Pedagógica e Universitária Ltda., 1986.

ANACHE, A. A. Quem é o sujeito da educação especial. In: REUNIÃO DA ASSOCIAÇÃO NACIONAL DE PÓS-GRADUAÇÃO E PESQUISA EM EDUCAÇÃO, 26., 2003. Poços de Caldas, MG. 2003. Novo governo. Novas políticas? Transparência apresentada no minicurso da ANPED.

ARANHA, M. S. F. A integração social do deficiente: análise conceitual e metodológica. In: REUNIẪO ANUAL DA SOCIEDADE DE PSICOLOGIA DE RIBEIRÃO PRETO, 24., 1994, Ribeirão Preto. Anais... Ribeirão Preto, 1994.

BRASIL. Conferência Nacional de Educação: construindo o sistema nacional articulado de educação: o plano nacional de educação, diretrizes e estratégias de ação. Brasília: MEC, 2010a.

. Constituição (1988). Constituição da República Federativa do Brasil. Brasília DF: Senado, 1999.

\section{. Declaração de Salamanca e linha de ação sobre necessidades} educacionais especiais. Tradução: Edílson Alkmim da Cunha. 2. ed. Brasília: CORDE, 1997.

Decreto no 7.611, de 17 de novembro de 2011. Dispõe sobre a educação especial, o atendimento educacional especializado e dá outras providências. Brasília, DF: Presidência da República, 2011a.

. Lei $\mathrm{n}$ 0 4.024/1961. Dispõe sobre lei de diretrizes e bases da educação nacional. Brasília, DF. Diário Oficial [da] República Federativa do Brasil, Brasília, DF, 27 dez. 1961. p. 11429. Disponível em: <http://www.planalto.gov.br/ccivil_03/leis//4024.htm>. Acesso em: 12 dez. 2014.

. Lei $\mathrm{n}^{\circ} 5.692$, de 11 de agosto de 1971. Fixa diretrizes e bases para o ensino de $1^{\circ}$ e $2^{\circ}$ graus, e dá outras providências. Revogada pela Lei no. 9.394, de 20 de dezembro de 1996. Diário Oficial [da] República Federativa do Brasil, Brasília, DF, 1971. Disponível em: <http://www.planalto.gov.br/ccivil_03/leis/l5692.htm>. Acesso em: 12 dez. 2014.

. Lei $\mathrm{n}^{\circ}$ 9.394, de 20 de dezembro de 1996. Estabelece as diretrizes e bases da educação nacional. Diário Oficial [da] República Federativa do Brasil, Brasília, DF, n. 248, 23 de dez. 1996.

. Lei $n^{\circ} 10.172$, de 9 de janeiro de 2001. Aprova o plano nacional de educação e dá outras providências. Diário Oficial [da] República Federativa do Brasil, Brasília, DF, 10 jan. 2001. p. 1. Disponível em: <http://www.planalto.gov.br/ccivil_03/leis/leis_2001//10172.htm>. Acesso em: 10 abr. 2018. 
. Ministério da Educação. Conselho Nacional de Educação. Câmara de Educação Básica. Parecer CNE/CEB no 13, de 10 de maio de 2012. Assunto: Diretrizes curriculares nacionais para a educação escolar indígena. Brasília, DF: MEC/CNE/CEB, 2012a.

. Parecer nำ 14 do Conselho Federal de Educação. Conselho Nacional de Educação - Câmara de Educação Básica. PARECER № 14/99, de 14 de setembro de 1999. Assunto: Diretrizes curriculares nacionais da Educação Escolar Indígena.

Resolução no 03 da Câmara de Educação Básica. RESOLUÇÃO CEB № 3, DE 10 DE NOVEMBRO DE 1999. Fixa Diretrizes Nacionais para o funcionamento das escolas indígenas e dá outras providências.

Resolução CNE/CEB no 5, de 22 de junho de 2012. Define diretrizes curriculares nacionais para a educação escolar indígena na educação básica. Brasília, DF: MEC/CNE/CEB, 2012b.

Resolução no 2, de 28 de abril de 2008. Estabelece diretrizes complementares, normas e princípios para o desenvolvimento de políticas públicas de atendimento da Educação Básica do Campo. Brasília, DF, 2008a. Disponível em: $<$ http://portal.mec.gov.br/arquivos/pdf/resolucao_2.pdf>. Acesso em: 11 jan. 2013.

Resolução no 7, de 14 de dezembro de 2010. Fixa diretrizes curriculares nacionais para o ensino fundamental de 9 (nove) anos. Brasília: MEC/CNE/CEB, $2010 b$.

Censo escolar da educação básica: 2011. Brasília, DF, 2011 b. Disponível em: http://<mec.gov.br>. Acesso em: 9 dez. 2013.

Censo escolar da educação básica: 2012. Brasília, DF, 2012c.

Disponível em:

<http://download.inep.gov.br/educacao_basica/censo_escolar/resumos_tecnicos/res umo_tecnico_censo_educacao_basica_2012.pdf>. Acesso em: $10 \mathrm{dez} .2013$.

. Microdados do censo escolar 2008. Brasília: MEC/INEP, 2008b.

. Microdados do censo escolar 2009. Brasília: MEC/INEP, 2009.

. Microdados do censo escolar 2010. Brasília: MEC/INEP, 2010c.

. Conselho Nacional de Educação. Resolução n. 1, de 15 de maio de 2006. Institui Diretrizes curriculares nacionais para o curso de graduação em pedagogia, licenciatura. Brasília, DF: MEC/CNE/CP, 2006.

. Política nacional de educação especial na perspectiva da educação inclusiva. Brasília, DF: MEC/SEESP, 2008c. MEC, 2002.

Referenciais para a formação de professores indígenas. Brasília, DF: 
Educação Indígena: escolarização e políticas...

. Ministério de Educação e do Desporto. Secretaria de Educação

Fundamental. Referencial curricular nacional para as escolas indígenas.

Brasília, DF: MEC/SEF, 1998.

BUENO, J. G. S. A educação do deficiente auditivo no Brasil: situação atual e perspectivas. Em Aberto, Brasília, ano 13, n. 60, p. 25-36, out./dez. 1993.

Educação inclusiva e escolarização dos surdos. Revista Integração, Brasília, DF: MEC, ano 13, n. 23, p. 37-42, 2001.

CADERNOS CEDES 23. Educação especial. São Paulo: Cortez, 1985.

CARVALHO, R. E. Nosso (des)compromisso social. In: SEMINÁRIO BRASILEIRO DE PESQUISA EM EDUCAÇÃO ESPECIAL, 2., 1991, Rio de Janeiro. Anais... Rio de Janeiro: UERJ, 1991.

COHN, C. Educação escolar indígena: para uma discussão de cultura, criança e cidadania ativa. Perspectiva. v. 23, n. 2, p. 485-515, jul./dez. 2005. Disponível em: <http://www. ced.ufsc.br/nucleos/nup/perspectiva.html>. Acesso em: 22 abr. 2011.

DICIONÁRIO HOUAISS. Deficiência. 2018. Disponível em: <https://houaiss.uol.com.br/pub/apps/www/v3-3/html/index.php\#1>. Acesso em: 25 jan. 2018.

ESCOLA PLURAL. O especial na educação: a experiência de Belo Horizonte. Belo Horizonte: Secretaria Municipal, nov. 2000. (Cadernos).

FONSECA, V. Educação especial. Porto Alegre: Artes Médicas, 1987.

GAIO, R.; MENEGUETTI, R. G. K. Caminhos pedagógicos da educação especial. Petrópolis: Vozes, 2004.

GROZADA, T. F. O ensino de geografia para alunos cegos ou baixa visão. Uberlândia, 2010.

GRUBITS, S.; SORDI, A. Pesquisas nas comunidades indígenas: relações de justiça e igualdade. Bol. Acad. Paul. Psicol., São Paulo, v. 37, n. 92, jan. 2017.

IBGE. Censo demográfico: 2005. Rio de Janeiro: IBGE, 2006. Disponível em: <https://ww2.ibge.gov.br/home/estatistica/populacao/trabalhoerendimento/pnad2005/ default.shtm>. Acesso em: 20 jan. 2018.

. Censo demográfico: 2010. Rio de Janeiro: IBGE, 2010. Disponível em: https://censo2010.ibge.gov.br/. Acesso em: 20 jan. 2018.

Censo escolar: 2015. Rio de Janeiro: IBGE, 2016. Disponível em: <https://files.comunidades.net/profemarli/censo_escolar_divulgacao_22032016.pdf>. Acesso em: 20 jan. 2018.

JANNUZZI, G. S. M. A luta pela educação do deficiente mental no Brasil. São Paulo: Cortez, 1992. 
JOMTIEN. Conferência Mundial de Educação para Todos. Declaração mundial sobre educação para todos. Jomtien: UNESCO, 1990.

LANCELOTTI, S. S. P. Deficiência e trabalho: redimensionando o singular no contexto universal. 2000. 123 f. Dissertação (Mestrado em Educação)- Universidade Federal de Mato Grosso do Sul, Campo Grande, MS, 2000.

MAZZOTTA, J. S. Educação especial no Brasil: história e políticas públicas. 5. ed. São Paulo: Cortez, 2005.

MELIÁ, B. Educação indígena na escola. Cadernos Cedes, Campinas: CEDES, n. 49, p. 11-17, dez. 1999.

MENDES, E. G. Educação especial: políticas públicas e concepções sobre deficiência. In: MARQUEZINE, M. C. ALMEIDA, M. A.; TANAKA, E. D. O. (Orgs.). Coleção perspectivas multidisciplinares em educação especial. (Educação Especial: políticas públicas e concepções sobre deficiência). Londrina: Editora UEL, 2003.

MENEZES, E. T. de; SANTOS, T. H. dos. Verbete educação indígena. In: DICIONÁRIO INTERATIVO DA EDUCAÇÃO BRASILEIRA. São Paulo: Midiamix, 2001. Disponível em: <http://www.educabrasil.com.br/educacao-indigena/>. Acesso em: 1. maio 2018.

NÓVOA, A. Formação de professores e profissão docente. In: (Coord.). Os professores e a sua formação. 3. ed. Lisboa, Portugal: Dom Quixote, 1997. p. 1534.

PESSOTTI, I. Deficiência mental: da superstição à ciência. São Paulo: Editora USP, 1994.

PLETSCH, M. D.; FONTES, R. S.; GLAT, R. O papel da educação especial no processo de inclusão escolar: a experiência da rede municipal de educação do Rio de Janeiro. In: REUNIÃO ANUAL DA ANPED, 29., 2006, Caxambu. Educação, cultura e conhecimento na contemporaneidade: desafios e compromissos. Anais... Caxambu: ANPED, 2006.

RODRIGUES, O. M. P. R. Educação especial: história, etiologia, conceitos e legislação vigente. In: CAPELLINI, V. L. M. F. (Org.). Práticas em educação especial e inclusiva na área da deficiência mental. Bauru: MEC/FC/SEE, 2008.

\section{SÁ, M. A. O escolar indígena com deficiência visual na região da Grande}

Dourados, MS: um estudo sobre a efetivação do direito à educação. 2011. 135 f. Dissertação (Mestrado em Educação)- Universidade Federal da Grande Dourados, Dourados, 2011.

SCHWARTZMANN, J. S. Histórico. In: (Org.). Síndrome. São Paulo: Mackenzie, 1999. 
SILVA, P. B. G. Educação e identidade dos negros trabalhadores rurais do Limoeiro. 1987. Tese (Doutorado em Educação)- Universidade Federal do Rio Grande do Sul, Porto Alegre, 1987.

SOUZA LIMA, A. C. de. Um grande cerco de paz: poder tutelar, indianidade e formação do Estado no Brasil. Petrópolis, RJ: Vozes, 1995.

SOUZA, V. P. S. Crianças indígenas Kaiowá e Guarani: um estudo sobre as representações sociais da deficiência e o acesso às políticas de saúde e educação em aldeias da região da Grande Dourados. 2011, 155 f. Dissertação (Mestrado em Educação)- Universidade Federal da Grande Dourados, Dourados, 2011.

UNICEF._Garantindo os direitos de crianças indígenas. 2004. Disponível em: <http://www.unicef.org.br>. Acesso em: 20 mar. 2018.

URQUIZA, A. H. A. Palco das diferenças, a escola faz a diferença... Série-Estudos, Campo Grande, MS, n. 18, p. 297-300, jul./dez. 2004.

VIVEIROS DE CASTRO, E. A inconstância da alma selvagem. São Paulo: CosacNaify, 2002. 